\title{
GEOLOGY OF THE PALEOCENE SEPULTURA FORMATION, MESA DE LA SEPULTURA, BAJA CALIFORNIA
}

\section{GEOLOGIA DE LA FORMACION SEPULTURA DEL PALEOCENO, EN MESA DE LA SEPULTURA, BAJA CALIFORNIA}

\author{
Patrick L. Abbott \\ Andrew D. Hanson \\ Celeste N. Thomson \\ Deirdre L. Logue \\ Kristine D. Bradshaw \\ Woody Joe Pollard \\ Thomas E. Seeliger \\ Department of Geological Sciences \\ San Diego State University \\ San Diego, California 92182-0337, U.S.A.
}

Recibido en septiembre de 1992; aceptado en noviembre de 1992

\begin{abstract}
At its Mesa de La Sepultura type area, the upper-lower to upper Paleocene Sepultura Formation lies with apparent disconformity on the lower Maastrichtian, marine upper slope and shelf deposits of the Rosario Formation. In places the uppermost Rosario Formation is marked by a kaolinite-rich paleosol. The Sepultura Formation is a deepening-upward sequence divided into a lower glauconitic-clastic member and an upper limestone member. The lower member has a basal plutonic-volcanic conglomerate overlain by sandstone containing abundant Tumitella peninsularis of late-early to early-late Paleocene age. The dominant lithology is calcite-cemented, glauconitic, fossiliferous arkose or lithic arkose of apparent Peninsular Ranges provenance. The beds contain abundant red algal nodules, storm deposits, and iron-stained corrosion surfaces. Terrigenous sediment influx was diverted so that the upper member is virtually pure limestone dominated by branching red algae fragments and forams but devoid of micrite. The Sepultura Formation at Mesa de La Sepultura is a carbonate sediment-dominated record of late-early to late Paleocene deepening that progressed from shallowest marine at the base to $200 \mathrm{~m}$ deep shelf waters at the top. During this time, terrigenous coarse sediment deposition was blocked here even though it dominated in areas to the north and south.
\end{abstract}

Key words: Paleocene, Sepultura, limestone, Baja California.

\section{RESUMEN}

En su área tipo de Mesa de la Sepultura, la Formación Sepultura del Paleoceno superior-inferior a superior yace en discordancia aparente sobre los depósitos de la plataforma y pendiente superior marinos de la Formación Rosario, del Mastrictiano medio. En algunos sitios el contacto superior de la Formación Rosario está marcado por un paleosuelo rico en caolinita. La Formación Sepultura es una secuencia que se hace más profunda hacia arriba, dividida en un miembro inferior clástico-glauconítico y un miembro superior calizo. El miembro inferior tiene un conglomeradoplutónico-volcánico basal, cubicrto por arenisca que contiene abundante Tumitella peninsularis del Paleoceno temprano tardio al tardío temprano. La litología dominante es arcosa fosilifera o lítica cementada con calcita glauconítica, que procede aparentemente del Batolito Peninsular. Las capas contienen abundantes nódulos de algas rojas y depósitos de tormenta, así como superficies de corrosión con manchas ferrosas. El flujo de sedimentos terrígenos fue desviado 
de modo que el miembro superior es casi caliza pura dominada por fragmentos de algas rojas ramificadas y foraminíferos pero carente de micrita. La Formacion Sepultura en Mesa de la Sepultura es un registro dominado por sedimentos de carbonatos, del Paleoceno tardío-temprano a tardío, que representa una sumersión o hundimiento desde ambientes marinos someros en la base de la columna hasta profundidades de plataforma de $200 \mathrm{~m}$ en la cima. Durante este tiempo, el depósito de sedimentos gruesos terrígenos fue inhibido aquí, aunque dominó en áreas al norte y sur de esta región.

Palabras clave: Paleoceno, Sepultura, caliza, Baja California.

\section{INTRODUCTION}

Mesa de La Sepultura is located in northern Baja California about $20 \mathrm{~km}$ southeast of El Rosario (Fig. 1). It is the type locality of the Paleocene/Eocene Sepultura Formation named by Santillán and Barrera (1930). The geomorphology of the mesa is vividly depicted by the name sepultura, which is an above ground burial site with a tombstone. Resistant limestone caps the mesa and a topographic high point on the west is reminiscent of a tombstone.

The distribution of Tertiary strata of Baja California is included on the map by Gastil et al. (1975). The Paleocene and Eocene units are typically described as deltaic and nearshore deposits (Beal, 1924; Gastil et al., 1975). Beal (1948) further suggested that the units reflect an important subsidence or advancing shoreline during which the sea covered the western flanks of the peninsula.

Kilmer (1963) mapped the Cretaceous and Tertiary sequence in the vicinity of $\mathrm{El}$ Rosario. He identified the invertebrate fossils and defined the stratigraphy of the Upper Cretaceous Rosario Group. Patterson (1978) furthered his work by studying the foraminifera and paleoecology of the uppermost $400 \mathrm{~m}$ of marine siltstone and sandstone of the Rosario Formation. She suggested a drastic downdropping of the Rosario basin to bathyal depths followed by gradual sediment buildup to shallower water depths. It is likely that the uppermost part of her section near E1 Rosario overlaps with the lowest part of the section exposed at Mesa de La Sepultura. Storm deposits in the Sepultura Formation were described and interpreted by LedesmaVázquez (1991).

Santillán and Barrera (1930) described the Sepultura Formation at Mesa de La Sepultura as principally green, grey, red and yellow sandstone with medium size conglomerate layers and rare, silty limestone. Since that

\section{INTRODUCCION}

Mesa de la Sepultura se localiza en el norte de Baja California, aproximadamente 20 $\mathrm{km}$ al sureste de El Rosario (Fig. 1). Es la localidad tipo de la Formación Sepultura del Eoceno/Paleoceno,denominada así por Santillán y Barrera (1930). La geomorfología de la meseta está vívidamente descrita por el nombre sepultura, ya que parece una elevada tumba de tierra con una lápida. La meseta está cubierta por caliza resistente y, al oeste, un punto topográfico alto evoca la lápida.

La distribución de estratos terciarios de Baja California se incluye en el mapa de Gastil et al. (1975). Las unidades del Paleoceno y Eoceno están descritas típicamente como depósitos deltaicos y de cercanía de costa (Beal, 1924; Gastil et al., 1975). Beal (1948) sugirió además que las unidades reflejan un hundimiento importante o avance de la línea costera, durante el cual el mar cubrió los flancos occidentales de la península.

Kilmer (1963) trazó la secuencia del Cretácico y Terciario en el área de El Rosario. Identificó los fósiles invertebrados y definió la estratigrafía del Grupo Rosario del Cretácico superior. Patterson (1978) continuó su trabajo con un estudio de los foraminíferos y la paleoecología de los $400 \mathrm{~m}$ superiores de limolita y arenisca marinas de la Formación Rosario. Esta investigadora considera que hubo una caída drástica de la cuenca Rosario a profundidades batiales, seguida de acumulación gradual de sedimentos a profundidades menores. Es probable que la parte superior de su sección cercana a El Rosario esté superpuesta a la parte inferior de la sección expuesta en Mesa de la Sepultura. Los depósitos de tormenta de la Formación Sepultura han sido descritos e interpretados por Ledesma-Vázquez (1991).

Santillán y Barrera (1930) describieron la Formación Sepultura de Mesa de la Sepultura como constituida principalmente por 


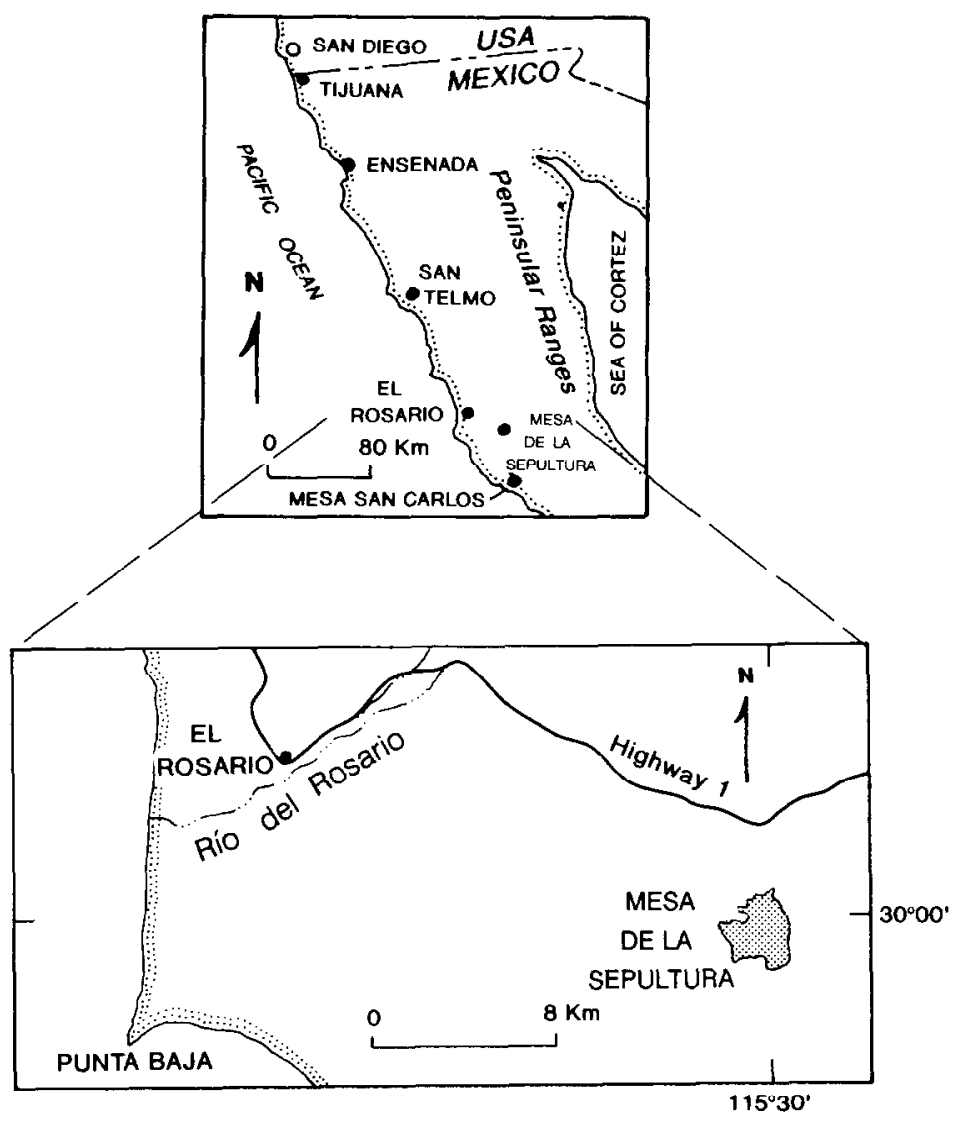

Figure 1. Location map.

Figura 1. Mapa de localización.

time, no detailed lithologic study has been completed.

Santillán and Barrera (1930) stated "...Pero el espesor que manifiesta arriba de la Formación Rosario no es de consideración en ninguno de los lugares donde aflora...", i.e., the Sepultura Formation is of no real importance because of its minor outcrop thickness. Admittedly, it is much thinner than the Rosario Group, but the Sepultura is of potentially grave importance. During Paleocene time, the Sepultura limestones were accumulating while to the north and south only terrigenous clastics were being deposited. Therefore, the Sepultura Formation provides important evidence in the reconstruction of the Paleocene paleogeography of northern Baja California. arenisca verde, gris, roja y amarilla, con capas de conglomerado de tamaño medio y escasa caliza limosa. Desde entonces no se ha completado ningún estudio litológico detallado.

Santillán y Barrera (1930) afirmaron "...Pero el espesor que se manifiesta arriba de la Formación Rosario no es de consideración en ninguno de los lugares donde aflora...". Es cierto que el afloramiento es mucho más delgado que en el Grupo Rosario, pero la Formación Sepultura es potencialmente importante. Durante el Paleoceno, las calizas de la Sepultura se fueron acumulando mientras al norte y al sur sólo se depositaban clásticos terrígenos. Por tanto, la Formación Sepultura proporciona importante evidencia para reconstruir la paleogeografía del Paleoceno del norte de Baja California. 


\section{DEFINITION OF THE SEPULTURA FOR- MATION}

At the type locality, Mesa de La Sepultura, both the Sepultura and the Rosario Formations are nearly flat-lying. In our lithologic study it was necessary to define more succinctly the base of the Sepultura Formation. Because the Sepultura Formation exhibits great lateral variation in lithology in Baja California, multiple criteria are here provided to help define the formation over this large geographical area.

The criteria used for defining the base of the Sepultura Formation are: a) a steep break in slope due to increased induration resulting from the increase in calcium carbonate percentage, b) an upsection change in color from the black and dark grey of the Rosario Formation to light grey, red, pink, and yellow, c) the gradual upsection increase in sand grain sizes in the uppermost Rosario Formation as well as the first appearances of one-clast thick conglomeratestringers, herald the approach to the Sepultura Formation, d) the local appearance of a palcosol developed on uppermost Rosario which is expressed as leached zones with distinct white, light-red and dark-red colored horizons and enrichment in clay minerals, e) pebble to small boulder, crystalline-clast conglomerates ranging from 0.5 to $5 \mathrm{~m}$ thick at the base of the Sepultura, and f) the first appearance of turritellids which occur in abundance near the base of the Sepultura Formation. By using all or some of the criteria listed above, the break between the Sepultura Formation and Rosario Group can be consistently determined.

Our investigation of the Sepultura Formation recognizes two members, a lower glauconitic and clastic member and an upper limestone member (Fig. 2). The lower member consists of calcite-cemented arkosic sandstones, volcanic clast-dominated conglomerates, tempestites, abundant glauconite peloids, and minor limestone. This lower member contains terrigenous clastic material similar to that of the Rosario Formation as well as a high content of limestone like the upper member of the Sepultura Formation. The limestones are typically sorted, red algal-fossil fragment biosparrudite. Fragmented molluscan fossils and calcareous red algae are common throughout both members of the Sepultura Formation.

\section{DEFINICION DE LA FORMACION SEPUL- TURA}

En la localidad tipo Mesa de la Sepultura, ambas formaciones, Sepultura y Rosario, yacen casi planas. En este estudio litológico fue necesario definir muy sucintamente la base de la Formación Sepultura. Puesto que dicha formación muestra mucha variedad lateral de litología en Baja California, se proporcionan aquí varios criterios para ayudar a definirla sobre esta gran área geográfica.

Los criterios usados para definir la base de la Formación Sepultura son: a) una discontinuidad en la pendiente debida al incremento en el porcentaje de carbonato de calcio, b) un cambio de color, del negro y gris obscuro, en la sección de arriba de la Formación Rosario, al gris claro, rojo, rosa y amarillo, c) el aumento gradual del tamaño de los granos de arena al ascender en la sección de arriba de la Formación Rosario superior, así como las primeras apariciones de capas de conglomerado grueso de un solo tamaño de grano, que anuncian la cercanía de la Formación Sepultura, d) la aparición local de un palcosuclo desarrollado en la Rosario superior, que se manifiesta como zonas blanqueadas con bien definidos horizontes coloreados de blanco, rojo claro y rojo oscuro, así como enriquecimiento en minerales de arcilla, e) conglomerados de clasto cristalino, cuyo tamaño es de guijarros a cantos rodados, de 0.5 a $5 \mathrm{~m}$ de grosor en la base de la Sepultura, y f) la primera aparición de turritéllidos, que ocurre en abundancia cerca de la base de la Formación Sepultura. Usando todos o algunos de los criterios arriba listados, se puede determinar consistentemente la separación entre la Formación Sepultura y el Grupo Rosario.

Nuestra investigación de la Formación Sepultura reconoce dos miembros, uno inferior glauconítico y clástico y otro superior calizo (Fig. 2). El miembro inferior consiste en areniscas arcósicas cementadas con calcita, conglomerados dominados por clasto volcánico, tempestitas, abundante oolita glauconítica y poca caliza. Este miembro inferior contiene material clástico terrígeno similar al de la Formación Rosario, así como un alto contenido de caliza, al igual que el miembro superior de la Formación Sepultura. Las calizas están separadas típicamente, bioesparudita con fragmentos de algas rojas fósiles. En cualquier parte de ambos miembros de la 
Abbott et al: : Geology of the Paleocene Sepultura Formation

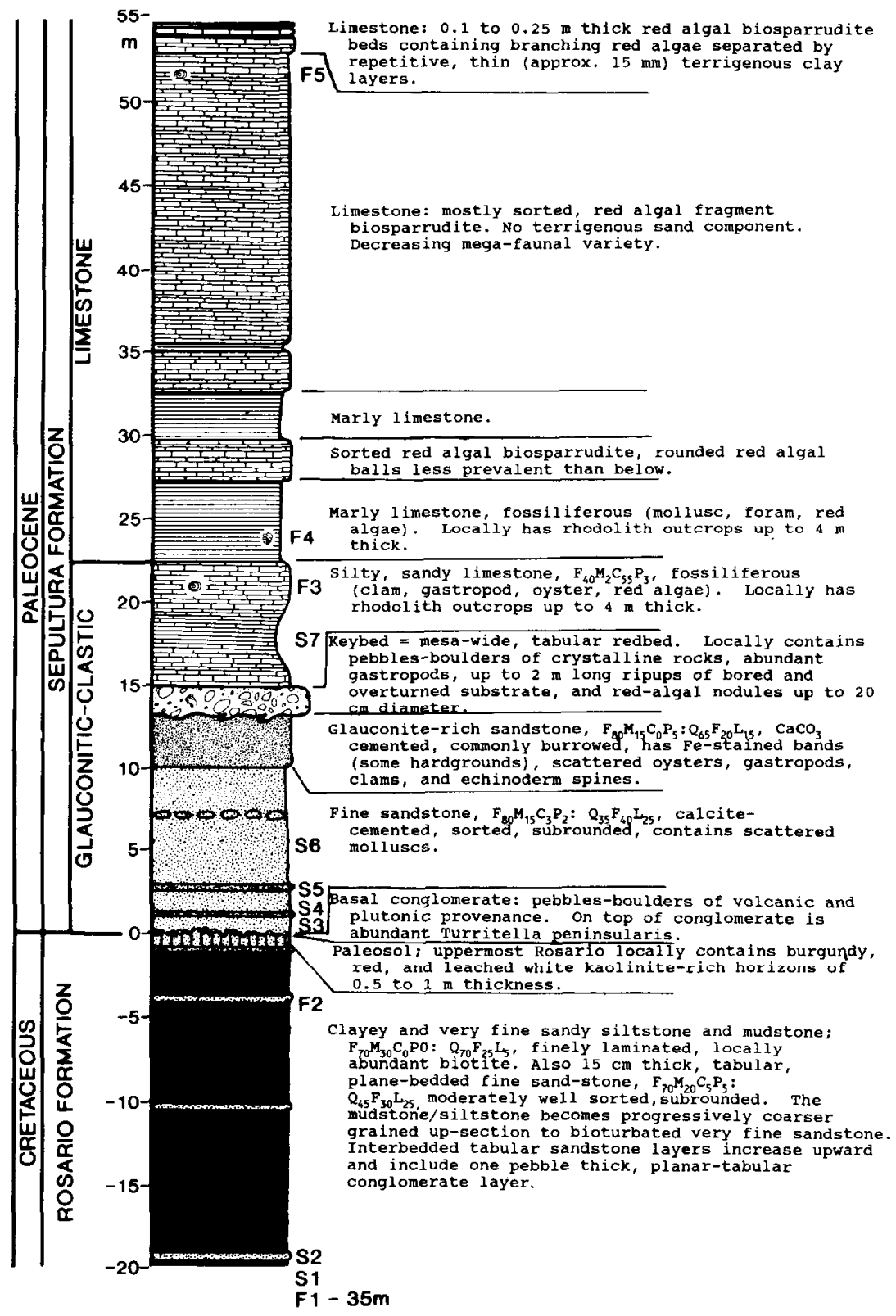

Figure 2. Generalized stratigraphic section for Mesa de La Sepultura. F = microfossil sample; $S=$ sandstone thin section.

Figura 2. Sección estratigráfica generalizada de Mesa de la Sepultura. F = muestra microfósil; $\mathrm{S}=$ sección delgada de arenisca. 
Table 1. Point-count data for sandstones.

Tabla 1. Datos de la cuenta de puntos para areniscas.

\begin{tabular}{lcccrcrc}
\hline Samples & S1 & S2 & S3 & S4 & S5 & S6 & S7 \\
\hline Quartz & 28.5 & 28.5 & 22.5 & 25.5 & 38.5 & 24.0 & 34.0 \\
Plagioclase & 19.0 & 22.0 & 17.5 & 18.0 & 14.0 & 17.5 & 10.5 \\
K-spar & 9.5 & 4.0 & 2.5 & 7.5 & 3.5 & 8.5 & 7.5 \\
VRF & 5.0 & 6.0 & 2.0 & 3.5 & 5.0 & 10.0 & 2.0 \\
MRF & 2.0 & 0 & 7.5 & 0.5 & 7.0 & 1.0 & 0 \\
SRF & 0 & 0 & 0 & 0.5 & 0 & 0 & 0 \\
Dense minerais & 18.5 & 23.5 & 17.0 & 18.0 & 16.0 & 10.5 & 11.5 \\
Biotite & 1.5 & 0.5 & 0.5 & 1.0 & 2.0 & 0.5 & 1.0 \\
Cement & 16.0 & 15.5 & 30.5 & 25.5 & 14.0 & 28.0 & 11.0 \\
\hline
\end{tabular}

$\mathrm{VRF}=$ volcanic rock fragments; $M R F=$ metamorphic rock fragments; $S R F=$ sedimentary rock fragments.

\section{LITHOLOGY OF THE ROSARIO FORMA- TION}

At Mesa de La Sepultura, the Rosario Formation consists of black to dark grey, planar laminar mudstone and siltstone interbedded with occasional $0.5 \mathrm{~m}$ thick beds of fine-grained arkose and lithic arkose. These sandstone beds are planar-tabular masses, contain planar laminations, and show no signs of post-depositional reworking by currents or deep waves. The likely origin of these sandstones was via episodic deposition from storm return-surge flows. The frequency of the sandstone beds increases upsection while the overall grain size coarsens slightly and gradationally as well.

Sandstone samples were examined petrographically (table 1) using thin sections which were stained for potassium feldspar and counted at 200 points per slide. The parameters of Dickinson et al. (1983) were utilized for provenance discrimination. Results are reproducible within 5\% (van der Plas and Tobi, 1965).

Samples S1 and S2 are from the Rosario Formation (see Fig. 2 for stratigraphic position). Both samples are fine-grained arkose with quartz-feldspar-lithic fragment (QFL) ratios averaging $\mathrm{Q}_{46} \mathrm{~F}_{44} \mathrm{~L}_{10}$. The low percentage of quartz and high percentage of feldspar with plagioclase percentage much greater than potassium feldspar indicate mineralogic immaturity. This probably reflects nearness to source, short transportation dis-
Formación Sepultura son comunes fragmentos de moluscos fósiles y algas rojas calcáreas.

\section{LITOLOGIA DE LA FORMACION ROSA- RIO}

En Mesa de la Sepultura, la Formación Rosario consiste en lodolita y limolita de color negro y gris oscuro, laminadas y planas, interestratificadas, con capas ocasionales, de $0.5 \mathrm{~m}$ de grueso, de arcosa de grano fino y arcosa lítica. Estas capas de arenisca son masas planas tabulares que contienen laminaciones planas y no muestran signos de alteraciones postdepositacionales causadas por corrientes u olas profundas. Probablemente, el origen de estas areniscas fue vía depositación episódica, proveniente del reflujo de oleajes de tormenta. La frecuencia de las capas de arenisca aumenta en la sección de arriba, a la vez que el tamaño general del grano se engrosa ligera y gradualmente.

Se examinaron muestras de arenisca petrográficamente (tabla 1), usando secciones delgadas que fueron teñidas para identificar el feldespato de potasio y contadas a 200 puntos por placa. Para determinar la procedencia, se utilizaron los parámetros de Dickinson et al.(1983). Los resultados son reproducibles dentro del 5\% (van der Plas y Tobi, 1965).

Las muestras S1 y S2 corresponden a la Formación Rosario (posición estratigráfica en Fig. 2). Ambas muestras son arcosa de grano fino con razones de fragmentos líticos de feldespato de cuarzo (QFL) promedio de $Q_{46}$ $\mathrm{F}_{44} \mathrm{~L}_{10}$. Los porcentajes bajo de cuarzo y 
tance, and little effect of chemical weathering. The low percentages of lithic fragments are partly due to the fine grain size. The provenance is plutonic with associated metamorphic and volcanic masses which is consistent with the Peninsular Ranges batholith and prebatholithic cover that lies to the east of Mesa de La Sepultura

Approaching the top of the Rosario Formation, the sand grain size increases to include fine-grained sandstone beds and oneclast thick, planar-based conglomerates. Locally, the uppermost $2 \mathrm{~m}$ is enriched in clay minerals and has dark-red, liglit-red, and white horizons interpreted to be a paleosol. This ancient soil is best exposed in the northeastern part of Mesa de La Sepultura. Table 2 contrasts the clay mineralogy of the colored horizons with that of the overlying Sepultura Formation. The presence of abundant kaolinite in the colored horizons suggests an advanced state of cation stripping and chemical weathering consistent with terrestrial exposure and weathering. The overlying Sepultura Formation has an abundance of expandable clays with subsidiary amounts of illite reflecting its submarine depositional site.

\section{MICROPALEONTOLOGY OF THE ROSA- RIO FORMATION}

Eighteen samples were collected from the Rosario Formation and were analyzed for four fossil groups: pollen and spores, siliceous microfossils, calcareous nannofossils (coccolithophores) and foraminifera. However, only the latter two provided assemblages with age and/or environmental significance.

Of the 18 Rosario samples only one provided a definitive faunal assemblage. The Maastrichtian stratigraphy in northern Baja California is very silty and sandy and the occurrence of samples barren in microfossils is a common phenomenon. The few microfossils present have been diluted by the increase in clastic material and post-burial solution is also likely to have dissolved many fossils. Sample F1 was collected $35 \mathrm{~m}$ below the Rosario-Sepultura contact. It contained Globotruncana elevata, G. arca, Rugoglobigerina rugosa, Frondicularia cf. inversa, Nodosaria septemcostata, N. spinifera, Praebulimina spinata, Pyramidina rudita, Anomalina rubiginosa, Gyroidinoides goudkoffi, $G$. cf. bandyi, Bolivina incrassata, Eponides ingra- alto de feldespato, con porcentaje de plagioclasa mucho mayor que de feldespato de potasio indican inmadurez mineralógica. Esto probablemente refleja cercanía con la fuente, corta distancia de transportación y poco efecto de intemperismo químico. Los bajos porcentajes de fragmentos líticos se deben en parte al tamaño fino del grano. La procedencia es plutónica con masas volcánicas y metamórficas asociadas, lo cual concuerda con la cubierta batolítica y prebatolítica del $\mathrm{Ba}$ tolito Peninsular que se extiende al este de Mesa de la Sepultura.

Cerca de la cima de la Formación Rosario, el tamaño del grano de arena aumenta hasta incluir capas de arenisca de grano fino y conglomerados gruesos de un solo tamaño de grano, de base plana. Localmente, los $2 \mathrm{~m}$ superiores están enriquecidos en minerales de arcilla y tienen horizontes de colores rojo oscuro, rojo claro y blanco, que se interpretan como un paleosuelo. La mejor exposición de este suelo antiguo está en la parte noreste de Mesa de la Sepultura. La tabla 2 contrasta la minerología de la arcilla de los horizontes coloreados con la de la superpuesta Formación Sepultura. La presencia de abundante caolinita en los horizontes coloreados sugiere un avanzado estado de denudación catiónica y química, acorde con la exposición terrestre y el intemperismo. La Formación Sepultura superpuesta tiene abundancia de arcillas explandibles con cantidades subsidiarias de ilita que reflejan su lugar de depositación submarina.

\section{MICROPALEONTOLOGIA DE LA FORMA- CION ROSARIO}

Se tomaron 18 muestras de la Formación Rosario y se analizaron en relación con cuatro grupos fósiles: polen y esporas, microfósiles silíceos, nanofósiles calcáreos (cocolitóforos) y foraminíferos. Sin embargo, sólo los dos últimos grupos fueron significativos en cuanto a edad $\mathrm{o} / \mathrm{y}$ ambiente.

De las 18 muestras, únicamente una proporcionó un grupo fáunico definitivo. $\mathrm{La}$ estratigrafía Mastrictiana en el norte de Baja California es muy cenagosa y arenosa, por lo que las muestras carentes de microfósiles son frecuentes. Los pocos microfósilespresentes se han diluido por el aumento de material clástico, y es probable también que la solución posterior al enterramiento haya disuelto mu- 
Table 2. Clay analysis.

Tabla 2. Análisis de arcilla.

\section{Sepultura Formation}

$\begin{array}{llrlr} & <4 \text { microns } & & <1 \text { micron } \\ +5 \text { m above contact } & \text { Illite } & 33 \% & \text { Illite } & 15 \% \\ & \text { Kaolinite } & 6 \% & \text { Kaolinite } & 7 \% \\ & \text { Expandable } & 61 \% & \text { Expandable } & 78 \%\end{array}$

\section{Rosario Formation}

$-0.3 \mathrm{~m}$ below contact

\begin{tabular}{|c|c|c|c|c|}
\hline \multirow{3}{*}{$-1 \mathrm{~m}$} & Illite & $6 \%$ & Illite & $2 \%$ \\
\hline & Kaolinite & $34 \%$ & Kaolinite & $\Delta c$ \\
\hline & Expandable & $60 \%$ & Expandable & \\
\hline \multirow{3}{*}{$-1.5 \mathrm{~m}$} & Illite & $23 \%$ & Illite & \\
\hline & Kaolinite & $17 \%$ & Kaolinite & \\
\hline & Expandable & $60 \%$ & Expandable & \\
\hline
\end{tabular}

mensis, Dentalina basiplanata, D. vistulae, Lenticulina spachholtzi, L. musensteri, and Lagena paucicosta. This assemblage is placed in the D2 zone of Goudkoff (1945) which is of earliest Maastrichtian age (Fig. 3). This correlates with the zone assigned to the uppermost Rosario Formation by Patterson (1978). Her lower El Viento member yielded a Praebulimina spinata zonule and was placed in the Goudkoff D2 zone which suggests that the top of the Rosario Formation near El Rosario overlaps with the base of the Rosario Formation at Mesa de La Sepultura. Sample F1 also revealed a low diversity coccolithophore assemblage: Micula decussata, Prediscosphera! sp., and Watznaueria bamesae, which are consistent with the CampanianMaastrichtian age date. The paleoenvironment is restricted by the occurrence of Praebulimina spinata, Gyroidinoides goudkoff and $G$. cf. bandyi foraminifera and is interpreted to be upper to midale bathyal (c. $500 \mathrm{~m}$ ) water depth. Sample F2 at $4.5 \mathrm{~m}$ below the Sepultura-Rosario contact contains a sparse Praebulimina spinata assemblage that suggests the same D2 zone. chos fósiles. La muestra $\mathrm{F} 1$ se recogió $35 \mathrm{~m}$ debajo del contacto Rosario-Sepultura. Contuvo Globotruncana elevata, G. arca, Rugoglobigerina rugosa, Frondicularia cf. inversa, Nodasaria septemcostata, N. spinifera, Praebulimina spinata, Pyramidina rudita, Anomalina rubiginosa, Gyroidinoides goudkoffi, $G$. cf. bandyi, Bolivina incrassata, Eponides ingramensis, Dentalina basiplanata, D. vistulae, Lenticulina spachholtzi, L. muensteri y Lagena paucicosta. Este conjunto está situado en la zona D2 de Goudkoff (1945), que es del Mastrictiano temprano (Fig. 3). Esto corresponde a la zona asignada por Patterson (1978) a la Formación Rosario superior. Su miembro inferior, El Viento, aportó una pequeña zona de Praebulimina spinata y fue asignada a la zona D2 de Goudkoff, lo que hace suponer que la cima de la Formación Rosario cercana a El Rosario se superpone a la base de la Formación Rosario en Mesa de la Sepultura. La muestra $F 1$ revela además un grupo poco diverso de cocolitóforos: Micula decussata, Prediscosphera? sp. y Watznaueria bamesae, que coinciden con la cdad dcl Campaniano-Mastrictiano. El paleoambiente está 

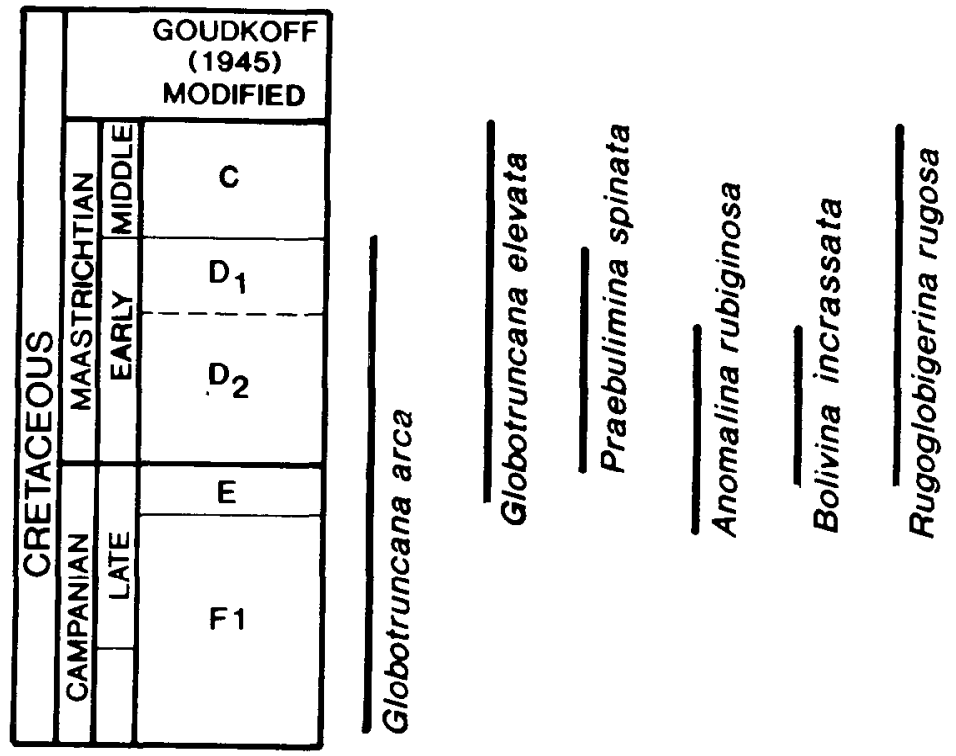

Figure 3. Ranges of some Rosario Formation foraminifera from sample F1.

Figura 3. Extensión temporal de algunos foraminíferos de la muestra F1 de la Formación Rosario.

\section{LITHOLOGY OF SEPULTURA FORMA- TION: LOWER GLAUCONITIC-CLASTIC MEMBER}

The basal bed of the Sepultura Formation is a jumbled, pebble- to boulder-size, crystalline-clast conglomerate that is $0.5 \mathrm{~m}$ thick and overlies the paleosol in the northeastern area of the mesa. This conglomeratic interval thickens to form a set of nested channels totaling $5 \mathrm{~m}$ thickness on the eastern side of the mesa where the paleosol has apparently been removed. The axes of the channels trend $\mathrm{N} 35^{\circ} \mathrm{W}$, i.e., the direction of paleocurrent flow. Clast counts made in the basal Sepultura Formation at two sites (NE mesa, $E$ mesa) show a dominance of volcanic clasts, subsidiary plutonic clasts, and lesser metamorphic and sedimentary clasts (table 3 ). The plutonic clasts within this conglomerate are highly weathered whereas the volcanic clasts are relatively unweathered. The clast assemblage is quite similar to that in the Sepultura Formation at San Telmo which lies about $110 \mathrm{~km}$ to the north (Miller and Abbott, 1988) (Fig. 1). Clast assemblages at both localities reflect the bedrock lithologies present in the Peninsular Ranges to the east. restringido por la presencia de foraminíferos Praebulimina spinata, Gymoidinoides goudkoffi y $G$. cf. bandyi, y se interpreta como de profundidad batial (c. $500 \mathrm{~m}$ ) superior a media. La muestra $F 2$, de $4.5 \mathrm{~m}$ debajo del contacto Sepultura-Rosario, contiene un grupo escaso de Praebulimina spinata, lo que sugiere la misma zona D2.

\section{LITOLOGIA DE LA FORMACION SEPUL- TURA: MIEMBRO INFERIOR CLASTICO- GLAUCONITICO}

El lecho basal de la Formación Sepultura es un conglomerado clástico cristalino de tamaño de guijarros a cantos, no gradado, que tiene $0.5 \mathrm{~m}$ de espesor y se superpone al paleosuelo en la parte noreste de la meseta. Este intervalo conglomerático se ensancha hasta formar un conjunto de canales encajados, que abarca $5 \mathrm{~m}$ de grosor, sobre el lado oriental de la meseta, donde el paleosuelo ha sido, al parecer, removido. La orientación de los ejes de los canales es $\mathrm{N} 35^{\circ} \mathrm{O}$, es decir, la dirección del flujo de la paleocorriente. Las cuentas de clastos efectuadas en dos sitios de la Formación Sepultura basal (al noreste y este de la meseta) muestran preponderancia de clastos volcánicos, clastos plutónicos sub- 
Table 3. Congiomerate clast counts.

Tabla 3. Cuentas de clasto conglomerado

$\begin{array}{lrr}\text { NE mesa } & \text { E mesa } & \text { San Telmo } \\ \mathrm{n}=109 & \mathrm{n}=107 & \end{array}$

\begin{tabular}{lrrr}
\hline Phenocrystic volcanic & 30 & 40 & 37 \\
Aphanitic volcanic & 27 & 25 & 27 \\
Plutonic & 22 & 22 & 22 \\
Metamorphic & 16 & 5 & 8 \\
Sedimentary & 2 & 5 & 3 \\
Other & 3 & 3 & 3 \\
\hline Total percentage & 100 & 100 & 100 \\
\hline
\end{tabular}

On the northeastern and northwestern sides of the mesa, the bed above the basal conglomerate is a fossiliferous sandstone rich in invertebrate fossils including abundant turritellids, oysters, clams, worm tubes, and echinoid debris. The orientation of elongate turritellid shells exposed on soles of beds on the northwest side again indicate a $\mathrm{N} 35^{\circ} \mathrm{W}$ paleocurrent direction. These turritellid shells almost at the base of the Sepultura Formation have been identified by Lou Ella Saul of the Los Angeles County Museum (personal communication, 1992) as Tunitella peninsularis Anderson and Hanna (1935) of late-early or early-late Paleocene age. It appears that the base of the Sepultura Formation at Mesa de La Sepultura is no older than late early Paleocene and that the uppermost Rosario Formation is likely to be no younger than mid-Maastrichtian age. Thus the Cretaceous/ Tertiary boundary section is missing due to nondeposition, weathering and erosion.

The lower member is resistant and stands as steep slopes due to abundant calcite cement. On the outcrop and in hand specimen, the interval commonly looks like calcitecemented, fossiliferous volcanic litharenite. However, deep acid etching of hand samples and thin-section analyses show that the dark sand grains are actually peloids of glauconite. The common components of the lower member are terrigenous sand $(\mathrm{S})$, calcium carbonate cement and fossils $(\mathrm{C})$, and glauconite $(\mathrm{G})$. Beds range from $\mathrm{S}_{89} \mathrm{C}_{10} \mathrm{G}_{1}$ to $\mathrm{S}_{2} \mathrm{C}_{97} \mathrm{G}_{1}$ to $\mathrm{S}_{43} \mathrm{C}_{32} \mathrm{G}_{25}$.

The normalized QFL terrigenous sand fractions range from $\mathrm{Q}_{63} \mathrm{~F}_{33} \mathrm{~L}_{4}$ to $\mathrm{Q}_{39} \mathrm{~F}_{43} \mathrm{~L}_{18}$ sidiarios y clastos sedimentarios y metamórficos menores (tabla 3). Dentro de este conglomerado, los clastos plutónicos son altamente intemperizados, mientras que los clastos volcánicos están relativamente sin erosionar. El ensamble de clastos es muy similar al de la Formación Sepultura en San Telmo, aproximadamente $110 \mathrm{~km}$ al norte (Miller y Abbott, 1988; Fig. 1). Los ensamblajes de clastos de ambas localidades reflejan las litologías de los basamentos presentes al este en el Batolito Peninsular. En los costados noreste y noroeste de la mesa, la capa sobre el conglomerado basal es arenisca fosilífera, rica en fósiles invertebrados, con abundantes turritélidos, ostiones, almejas, tubos de gusanos y restos de equinoideos. La orientación de las conchas alargadas de turritélidos expuestas en las bases de las capas del lado noroeste también indican dirección $\mathrm{N} 35^{\circ} \mathrm{O}$ de la paleocorriente. Estas conchas de turritélidos, casi en la base de la Formación Sepultura, fueron identificadas por Lou Ella Saul del Los Angeles County Museum (comunicación personal, 1992) como Turitella peninsularis Andersony Hanna (1935) del Paleoceno temprano tardío o tardío temprano. Al parecer, la base de la Formación Sepultura en Mesa de la Sepultura no es anterior al Paleoceno temprano tardío y la Formación Rosario Superior no es, probablemente, posterior a la edad media Mastrictiana. En consecuencia, falta la sección límite Cretácico-Terciaria, debido a carencia de depósitos, intemperismo y erosión.

El miembro inferior es resistente y se levanta como escarpadas pendientes a causa del abundante cemento de calcita. En el 
with all samples (S3 to S7) being either arkose or lithic arkose. The sand grain populations were similar in both the upper Rosario and lower Sepultura Formations (table 1). The upper member of the Sepultura is effectively free of terrigenous sands.

Glauconite is a distinctive component and is unique to the lower member of the Sepultura Formation. It has a characteristic green color and occurs mostly as structureless peloids although some show internal cracking. Glauconite commonly makes up 1 to $15 \%$ of the framework grains but is concentrated up to $38 \%$ in some beds of storm or tsunami origin. In general, glauconite is made of green, iron-rich $\left(>15 \% \mathrm{Fe}_{2} \mathrm{O}_{3}\right)$ clay minerals. They are most abundant in deposits containing burrows and fossil debris that are associated with condensed zones and corrosion surfaces/hardgrounds. In the stratigraphic record their greatest abundance is associated with the transgressions and sea-level highstands of 1) early Cambrian to middle Ordovician and 2) mid-Cretaceous to Eocene time. Glauconite is commonly found in depositional environments ranging from embayment to $200 \mathrm{~m}$ water depth but is most abundant on current-swept shelves of 10-50 m depth (Van Houten and Purucker, 1984).

The glauconite at Mesa de La Sepultura fits the global generalizations. It is found in Paleocene strata deposited in a sea that transgressed over a paleosol and its greatest concentrations are in marine shelf tempestites. The glauconite-bearing beds are burrowed, contain abundant fossil debris and some iron-stained horizons that may be corrosion surfaces.

A most distinctive bed occurs throughout Mesa de La Sepultura in the lower member of the Sepultura Formation. It is an easily visible, unique redbed that derives its color from oxidized glauconite. It was deposited as a tabular mass of jumbled crystalline rock clasts, terrigenous sand, fossils, and glauconite that were concentrated by hurricane or tsunami waves and swept seaward by a storm-return surge. The high energy moving sediment mass dug into the marine floor in several places and injected sediment Into the underlying bed (negative flame structures). The injection features show a paleoslope/paleoflow direction of $\mathrm{N} 35^{\circ} \mathrm{W}$ consistent with the nested conglomeratic channels and aligned Tumitella shells. The redbed ranges in thickness from 0.2 to $1.5 \mathrm{~m}$ and locally contains afloramiento y en especímenes de mano, el intervalo generalmente tiene apariencia de litarenita volcánica fosilífera cementada con calcita. Sin embargo, el lavado con ácido de las muestras de mano y análisis de sección delgada muestran que los granos oscuros de arena son en realidad oolitass de glauconita. Los componentes comunes del miembro inferior son arena terrígena (S), cemento de carbonato de calcio y fósiles (C), y glauconita (G). Las capas van de $\mathrm{S}_{89} \mathrm{C}_{10} \mathrm{G}_{1}$ a $\mathrm{S}_{2} \mathrm{C}_{97} \mathrm{G}_{1}$ a $\mathrm{S}_{43} \mathrm{C}_{32} \mathrm{G}_{25}$.

Las fracciones normalizadas de arena terrigena de QFL van de $\mathrm{Q}_{63} \mathrm{~F}_{33} \mathrm{~L}_{4}$ a $\mathrm{Q}_{39} \mathrm{~F}_{43}$ $\mathrm{L}_{18}$ y todas las muestras ( $\mathrm{S} 3$ a $\mathrm{S} 7$ ) son arcosa o arcosa lítica. Las poblaciones de granos de arena fueron similares en las formaciones Rosario superior y Sepultura inferior (tabla 1). E1 miembro superior de la Sepultura está prácticamenıe libre de arenas terrígenas.

La glauconita es un componente característico, que únicamente se encuentra en el miembro inferior de la Formación Sepultura. Tiene un peculiar color verde y se encuentra principalmente como oolitas sin fábrica, aunque a veces con agrietamiento interno. $\mathrm{La}$ glauconita comúnmente constituye de 1 a $15 \%$ de los granos de la fábrica, pero se concentra hasta $38 \%$ en algunas capas originadas por tormenta o tsunami. En general, la glauconita está compuesta de minerales arcillosos verdes, ricos en hierro ( $>15 \% \mathrm{Fe}_{2} \mathrm{O}_{3}$ ). Estos son más abundantes en depósitos que contienen restos de perforaciones y restos de fósiles, que se asocian con zonas condensadas y corrosión de superficies o suelos duros. En el registro estratigráfico, su mayor abundancia se asocia con las transgresiones y niveles de plcamar del: 1) Cámbrico temprano al Ordoviciano medio y 2) del Cretácico medio al Eoceno. La glauconita se encuentra comúnmente en ambientes depositacionales que van desde ensenadas hasta aguas de $200 \mathrm{~m}$ de profundidad, pero es más abundante en plataformas de 10 a $50 \mathrm{~m}$ de profundidad barridas por corrientes (Van Houten y Purucker, 1984).

La glauconita de Mesa de la Sepultura se ajusta a las generalizaciones globales. Se encuentra en estratos del Paloeceno depositados en un mar que trasgredió un paleosueloy sus mayores concentraciones están en las tempestitas de la plataforma marina. Las capas portadoras de glauconita están perforadas, contienen abundantes restos fósiles y algunos horizontes manchados de hierro que pueden ser superficies de corrosión. 
varying concentrations of red algal-encrusted balls (rhodoliths), oysters-clams-snails, and crystalline rock pebbles-cobbles-boulders. Also entrained in the redbed were pieces of wood up to $1 \mathrm{~m}$ long, once occupied by calcareous worm colonies, and a $0.7 \mathrm{~m}$ long sandstone clast with bore holes now lying upside down in the deposit.

\section{MICROPALEONTOLOGY OF SEPULTURA FORMATION}

The lowest productive microfossil sample (F3) in the Sepultura Formation was near the top of the lower member. The nannofossil species Coccolithus pelagicus, Ericsonia sub-

pertusa, Prinsius sp., Toweius eminens? and $T$. pertusus? are parts of a late Paleocene assemblage that overlaps calcareous nannofossil zones CP5 to CP8 (Fig. 4). The first definitive foraminiferal fauna was recovered in the lower upper member (sample F4). It contained Bulimina aff. whitei, Cibicides sandiegensis, Anomalinoides aragonensis, $A$. aff. crassiseptus, A. garzaensis, Alabamina sp., Frondicularia sp., Astacolus sp., Textularia sp., Lenticulina spp., Vaginulina sp., Globulina sp., "Valvulineria" cf. childsi, Subbotina triangularis, S. t. cancellata, S. triloculinoides, $S$. linaperta, Globorotalia quadrilocula, $G$. pseudobulloides, G. compressa, Globigerina cf. spiralis, Morozovella crosswicksensis?, M. convexa? and $M$. spp. The genus Morozovella did not appear until P3 time and its occurrence helps bracket the sample; this is early late Paleocene time (Fig. 5). The lack of large benthic foraminifera and the abundance of Anomalinoides garzaensis and Bulimina aff. whitei (both are species which do not inhabit the shallow shelf) suggest a middle to outer shelf depositional environment and a water depth of about $100 \mathrm{~m}$ to possibly $200 \mathrm{~m}$.

The uppermost productive sample (F5) was collected near the top of the tombstone on the west side of the mesa. It was barren of foraminifera but revealed a low diversity coccolithophore flora. A late Paleocene age was indicated by the overlapping ranges of Fasciculithus tympanifomis and Placozygus signoides (late Maastrichtian to Paleocene). Other taxa found were Braarudosphaera bigelowii, Coccolithus sp. aff. C. pelagicus, and Coccolithus pelagicus.
Una capa muy característica se encuentra a través de toda Mesa de la Sepultura, en el miembro inferior de la Formación Sepultura. Es una única capa roja, fácil de observar, cuyo color se deriva de la glauconita oxidada. Se depositó como una masa tabular de clastos rocosos cristalinos mezclados, arena terrígena, fósiles y glauconita que fueron concentrados, por olas de huracán o tsunami y barridos hacia el mar por una oleada de reflujo de tormenta. La masa de sedimento movida con gran energía cavó en diferentes lugares del suelo marino e inyectó sedimento en la capa subyacente (estructuras de flama negativa). Las características de la inyección muestran una paleopendiente o paleoflujo en dirección $\mathrm{N} 35^{\circ} \mathrm{O}$, que concuerda con la de los canales encajados de conglomeráticoy la alineación de las conchas de Tumitella.

El espesor de la capa roja varía de 0.2 a $1.5 \mathrm{~m}$ y contiene localmente concentraciones diferentes de bolas con algas rojas incrustadas (rodolitos), así como ostiones, almejas y caracoles, además de guijarros, guija y cantos de roca cristalina. Alineadas en la capa roja hay además piezas de madera de hasta $1 \mathrm{~m}$ de largo, ocupadas en otro tiempo por colonias de gusanos calcáreos, así como un clasto de arenisca de $0.7 \mathrm{~m}$ de largo con perforaciones que ahora yacen con la parte superior hacia abajo sobre el depósito.

\section{MICROPALEONTOLOGIA DE LA FORMA- CION SEPULTURA}

La muestra microfosil menos productiva (F3) de la Formación Sepultura se tomó cerca de la cima del miembro inferior. Las especies nanofósiles Coccolithus pelagicus, Ericsonia subpertusa, Prinsius sp., Toweius eminens?, y $T$. pertusus? son partes de un escaso conjunto del Paleoceno tardío que se superpone a las zonas de nanofósiles calcáreos CP5 a CP8 (Fig. 4). La primera fauna foraminífera definitiva fue recuperada en la parte inferior del miembro superior (F4). Esta contuvo Bulimi$n a$ af whitei, Cibicides sandiegensis, Anomalinoides aragonensis, $A$. af. crassiseptus, $A$. garzaensis, Alabamina sp., Frondicularia sp., Astacolus sp., Textularia sp., Lenticulina spp.; Vaginulina sp., Globulina sp., "Valvulineria" cf. childsi, Subbotina triangularis, S. t. cancellata, S. triloculinoides, S. linaperta, Globoro- 

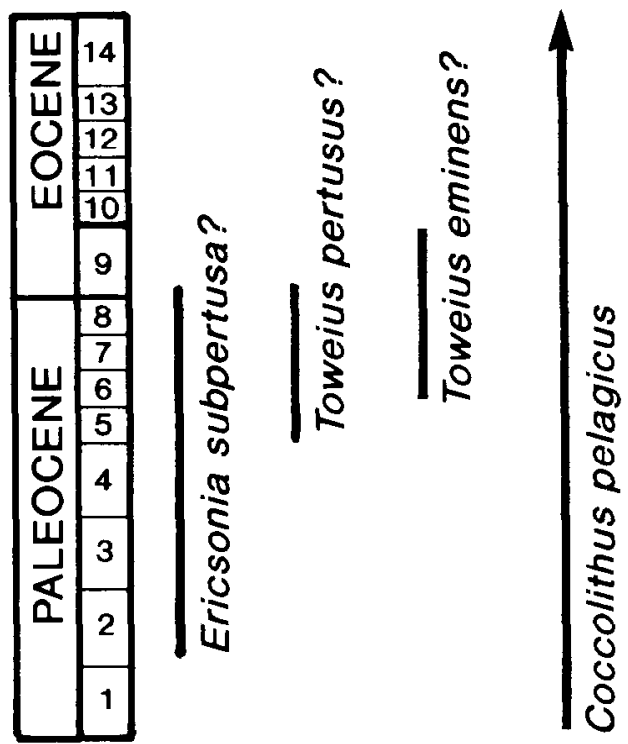

Figure 4. Ranges of some Sepultura Formation coccoliths from sample F4.

Figura 4. Extensión temporal de algunos cocolitos de la muestra F4 de la Formación Sepultura.
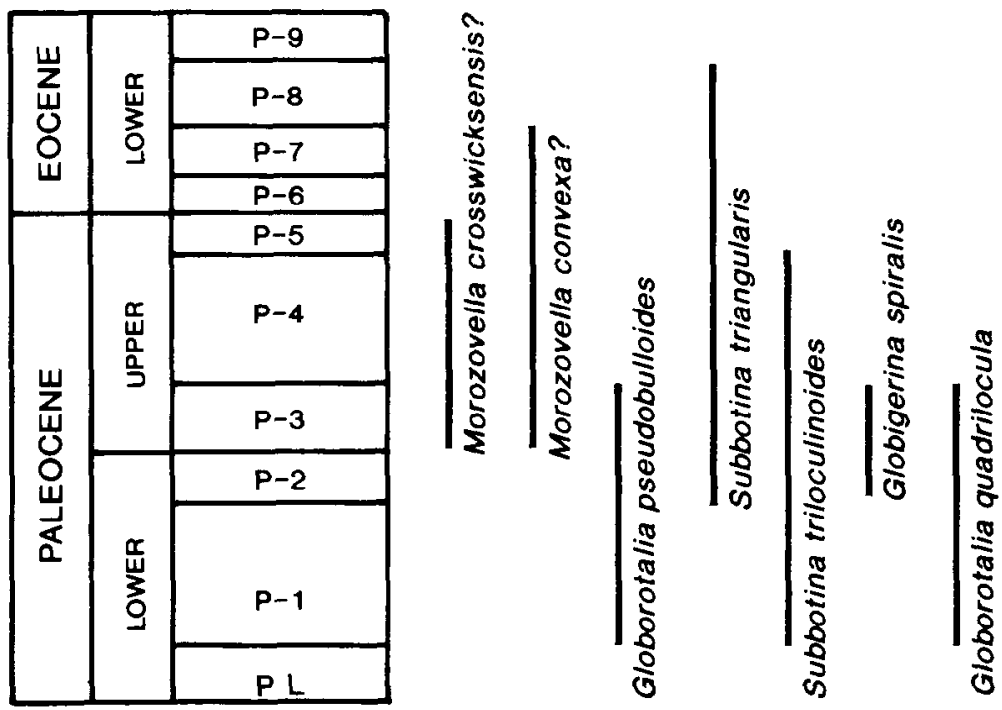

Figure 5. Ranges of some Sepultura Formation foraminifera from sample F4. Figura 5. Extensión temporal de algunos foraminíferos de la muestra F4. 


\section{LITHOLOGY OF SEPULTURA FORMA- TION: UPPER LIMESTONE MEMBER}

Conformably overlying the lower member of the Sepultura Formation is an upper limestone member which caps the entire mesa. The limestone beds are resistant to weathering and stand tall along steep faces. In many places the nearly flat-lying beds form stair-step ledges.

Samples were collected from varying stratigraphic levels on the east, central, and west sides of the mesa. Petrographical analyses of 13 thin sections revealed that all samples are cemented with very fine- to medium-crystalline sparry calcite; no micrite was noted. Syntaxial rims have formed around some echinoid fragments to create a poikilotopic texture. Visible in thin-section is abundant fossil debris: ubiquitous coralline red algae, common foraminifera such as miliolids, rotalids, uniserial and biserial benthic forams, gastropods, oysters, clams, echinoid debris, calcareous worm tubes, bryozoa and some ostracods. The diversity of fauna decreases with increasing stratigraphic level and at the western tombstone summit of the mesa, only red algae and foraminifera arc obscrved. The abundance of fauna does not show a corresponding decrease.

Architectural analysis (percentages of framework, matrix, cement, porosity = FMCP) reveals no porosity in any thin sections. Additionally, most samples have zero to minor (5\%) matrix component. Where matrix material is seen, it is generally very fine-grained hiotite and less commonly white mica.

The remaining components show a framework/cement ratio greater than one. Framework values range from 55 to $90 \%$ and cement values correspondingly range from 45 to $10 \%$. Although no statistical trend exists, it appears that the amount of cement slightly increases upsection with a corresponding decrease in framework. In all samples the primary framework component is skeletal debris. The most commonly identified grains are red algae which range from 58 to $98 \%$ with an average of 70 to $90 \%$. Other biological grains in decreasing order are foraminifera, echinoderm, bryozoa, oyster, and ostracod.

The red algae display morphological changes at differing stratigraphic levels. In the talia quadrilocula, $G$. pseudobulloides, $G$. compressa, Globigerina cf, spiralis, Morozovella crosswicksensis?, $M$. convexa? y $M$. spp. El género Morozovella no apareció hasta el tiempo P3 y su ocurrencia ayudó a delimitar la muestra; ésta es del Paleoceno tardío temprano (Fig. 5). La falta de foraminíferos bénticos grandes y la abundancia de Anomalinoides garzaensis y Bulimina af. whitei (ambas son especies que no habitan la plataforma somera) sugieren un ambiente de plataforma de media a exterior y una profundidad en el agua de aproximadamente $100 \mathrm{~m}$ hasta posiblemente $200 \mathrm{~m}$.

La muestra productiva de la parte más alta (F5) se recogió cerca de la cumbre de la lápida en el lado oeste de la meseta. Carecía de foraminíferos pero reveló una baja diversidad de flora cocolitófora. Se estableció que correspondía a la época tardía del Paleoceno, por la superposición de las extensiones temporales de Fasciculithus tympaniformis y Placozygus signoides (Mastrictiano tardío a Paleoceno) El resto de las especies encontradas, Braanudosphaera bigelowii, Coccolithus sp. af. C. pelagicus y Coccolithus pelagicus no fueron específicas para ninguna biocronozona.

\section{LITOLOGIA DE LA FORMACION SEPUL- TURA: MIEMBRO SUPERIOR CALIZO}

Sobreyaciendo de conformidad con el miembro inferior de la Formación Sepultura hay un miembro superior calizo que corona la meseta entera. Las capas calizas son resistentes al intemperismo y se yerguen altas a lo largo de los empinados costados. En muchos lugares estas capas que yacen casi planas forman salientes escalonados.

$\mathrm{Se}$ recogieron muestras de diferentes niveles estratigráficos sobre los lados oriental, central y occidental de la meseta. El análisis petrográfico de trece secciones delgadas reveló que todas las muestras estaban cementadas con calcita espática cristalina de muy fina a mediana; no se observó micrita. Alrededor de algunos fragmentos de equinoideos se han formado anillos sintaxiales que crean una textura poiquilotópica. En sección delgada son visibles abundantes restos fósiles: ubicuas algas rojas coralinas, foraminiferos comunes como los miliólidos, rotálidos, foraminíferos bénticos uniseriales y biseriales, gastrópodos, 
lower part of the limestone member the algae occur as subspherical rhodoliths. These are up to $20 \mathrm{~cm}$ in diameter and some outcrops are composed entirely of clast-supported rhodoliths. The most abundant rhodoliths are in the southeastern mesa. Going upsection the size of the rhodoliths decreases and the algae take on a branching morphology. This variation is present on both the macro- and microscopic scale. At the western summit of the mesa the layers of limestone that contain the branching red algal fragments are intercalated with thin $(<10 \mathrm{~mm})$ laminations of clay.

In thin section, the red algae display the characteristic feature of "closely packed layers or threads of cells, rectangular in section" (Ginsburg et al., 1971), placing them in the Fanily Corallinaceae. This family is divided into the subfamilies Melobesioideae (forming crusts, nodules, and rigid branched forms) or Corallinoideae (having erect, articulated or jointed shape). The red algae of Mesa de La Sepultura clearly belong in the Melobesioideae subfamily.

Using the classification scheme of Wray (1977), the genera Lithothamnion Heydrich (1897) and Archeolithothamnion Foslie (1898) were identified. These classifications are based upon the presence of sporangial sori and a multilayered hypothallium for Archeolithothamnion, and the presence of multipored conceptacles and a multilayer hypothallium for Lithothamion. In some thin sections the two genera are actually encrusting upon each other.

\section{DEPOSITIONAL HISTORY}

From a broad perspective, the Rosario Formation at Mesa de La Sepultura records a shallowing-upward sequence in early and middle Maastrichtian time. Subaerial exposure created soils that were flooded by a deepening-upward succession recorded in the Sepultura Formation in late-early to late Paleocene time.

The lowermost Rosario Formation at Mesa de La Sepultura is mainly gray, organicrich mudstone with rare tabular packages of plane-bedded sandstones apparently brought by energetic storm-return flows and deposited below storm-wave base. Foraminifera suggest water depths as deep as $500 \mathrm{~m}$ corresponding to an upper slope environment. All sedimen- ostras, almejas, restos de equinoideos, tubos calcáreos de gusanos, briozoarios y algunos ostrácodos. La diversidad de la fauna disminuye según aumenta el nivel estratigráfico $\mathrm{y}$, en la cima occidental de la lápida de la meseta, sólo se observaron algas rojas y foraminíferos. La abundancia de fauna no muestra una disminución correspondiente.

$\mathrm{El}$ análisis arquitectural (porcentajes de fábrica, matriz, cemento, porosidad = FMCP) no revela porosidad en ninguna de las secciones delgadas. Además, la mayoría de las muestras tienen de cero a menor (5\%) componente de matriz. Donde se observa material de matriz, este es, en general, biotita de grano muy fino $y$, menos comúnmente, mica blanca.

El resto de los componentes muestra una proporción de cemento/fábrica mayor de uno. Los valores de fábrica van de 55 a $90 \%$ y los de cemento de 45 a $10 \%$. Aunque no hay una tendencia estadística, parece que la cantidad de cemento aumenta ligeramente sección arriba, con la disminución correspondiente de fábrica. En todas las muestras, el componente primario de la fábrica lo constituyen restos de esqueletos. Los granos más comúnmente identificados son algas rojas que van de 58 a $98 \%$, con un promedio de 70 a $90 \%$. Otros granos biológicos en orden decreciente son foraminíferos, equinodermos, briozoos, ostiones y ostrácodos.

Las algas rojas exhiben cambios morfológicos en diferentes niveles estratigráficos. En la parte inferior del miembro calizo las algas se encuentran como rodolitos subesféricos. Estos son de hasta $20 \mathrm{~cm}$ de diámetro y algunos afloramientos se componen enteramente de rodolitos sustentados en clasto. Los rodolitos más abundantes están en la meseta sureste. Hacia arriba de la sección, la talla de éstos disminuye y las algas adoptan una morfología ramificada. Esta variación está presente tanto a escala microscópica como macroscópica. En la cumbre occidental de la meseta, las capas de caliza que contienen los fragmentos de algas rojas ramificadas están intercaladas con láminas delgadas $(<10 \mathrm{~mm})$ de arcilla.

En sección delgada, las algas rojas muestran el rasgo característico de "capas empacadas apretadamente o sartas de celdas, en sección rectangular" (Ginsburg et al.,1971), que las ubica en la familia Coralinaceae. Esta familia se divide en las subfamilias Melobesioideae (que forma cortezas, nódulos y 
tary features exposed show flat-lying, tabular beds and laminae without evidence of scour or gravity-pulled slippage; this suggests an outer shelf environment

Moving upsection through the Rosario Formation, the grain sizes begin to increase until very fine sands dominate and more tabular packages of plane beds occur. Near the top of the Formation, planar-based, one-clast thick conglomerates appear suggesting proximity to the shoreline. This uppermost Rosario Formation is a shallowing-upward sequence consistent with sediment buildup but the $50 \mathrm{~m}$ of section probably represents about $400 \mathrm{~m}$ of shallowing thus suggesting that regression/uplift occurred.

The uppermost Rosario Formation was exposed to subaerial soil-forming processes. How much sedimentary record was lost to this weathering plus nondeposition/erosion is not known at this time. However, it is likely that several million years of time is not represented by rock and that the Cretaceous/Tertiary boundary is not preserved.

When sedimentation was preserved again in the Sepultura Formation during Paleocene time it began as high energy, conglomeratic deposits in shallow marine water. Sedimentation rates were low as suggested by the abundance of glauconite, the presence of corrosion surfaces, and the importance of storm deposits. Paleocene sedimentation records a deepening of marine water and progressive separation from the terrigenous sediment influx of plutonic-volcanic-mctamorphic gravels and sands. The lower member displays other features indicative of a shallow marine environment including burrows, abundant marine invertebrate fossils, nested conglomerate-filled channels, oriented gastropods, abundant glauconite, and red algae.

Coralline red algae live in normal marine salinity environments and since they utilize sunlight they are restricted to the photic zone (Wray, 1977). Morphological changes noted in the red algae have been shown by Bosence (1991) to be the result of turbulence and water energy. The rhodolith variety is typical of higher energy conditions whereas the branching forms are found in quieter, presumably decper water. Boscnce also lists bathymetric ranges of $4010100 \mathrm{~m}$ for Lithothamnion and Archeolithothamnium. The up-section increase in branching red algae and decrease in rhodoliths support a model of ramas rígidas) o Corallinoideae (que tiene forma erecta, articulada o de coyuntura). Las algas rojas de Mesa de la Sepultura pertenecen claramente a la subfamilia Melobesioideae.

Usando el esquema de clasificación de Wray (1977), se identificaron los géneros Lithothamnion Heydrich (1897) y Archeolithothamnion Foslie (1898). Estas clasificaciones se basan en la presencia de soros esporangiales e hipotalo de varias capas, para Archeolithothamnion, y de conceptáculos multiporosos y hipotalo de varias capas, para Lithothammion. En algunas secciones delgadas, los dos géneros están en realidad incrustados uno sobre el otro.

\section{HISTORIA DEPOSITACIONAL}

Desde una perspectiva amplia, la Formación Kosario en Mesa de la Sepultura registra una secuencia que se hace más somera hacia arriba en la época temprana y media del Mastritciano. La exposición subaérea creó suelos que fueron inundados por una sucesión que se profundiza hacia arriba, grabada en la Formación Sepultura entre el Paleoceno tardío temprano y tardío.

La Formación Rosario inferior en Mesa de la Sepultura es principalmente lodolita gris, orgánicamente rica, con escasos paquetes tabulares de areniscas en lechos planos, aparentemente traídos por enérgicas corrientes de reflujo y depositados bajo la base de la ola de tormenta. Los foraminíferos hacen suponer profundidades acuáticas tan hondas como $500 \mathrm{~m}$, que corresponden a un ambiente de pendiente superior. Todos los rasgos sedimentarios expuestos muestran lechos tabulares planos y láminas sin evidencia de estrías o deslizamientos causados por gravedad, lo que hace suponer un ambiente de plataforma exterior.

Moviéndose hacia la sección de arriba a través de toda la Formación Rosario, los tamaños del grano comienzan a aumentar hasta que dominan arenas muy finas y se encuentran más paquetes tabulares de lechos planos. Cerca de la parte superior de la Formación aparecen gruesos conglomeradosde un solo tamaño de grano, con base plana, que sugieren la proximidad de la costa. Esta Formación superior Rosario es una secuencia que se hace somera hacia arriba, consistente con la acumulación de sedimentos, pero los $50 \mathrm{~m}$ de sección probablemente representan 
deepening water depths. Micropaleontology data from foraminifera suggest a middle to outer shelf environment for the upper limestone member.

Additionally, Adey and Macintyre (1973) list Archeolithothammium as a warm water genus and Lithothamnium as a cool water genus. Both genera occur together at Mesa de La Sepultura suggesting that these rocks were deposited at some mid-latitude where the geographic distributions of these genera could overlap.

By early late Paleocene time, only carbonate sediments were accumulating (along with minor amounts of phyllosilicates) even though terrigenous coarse sands and gravels were being deposited apparently at the same time at San Telmo, $110 \mathrm{~km}$ to the north (Miller and Abbott, 1988) and at Mesa San Carlos, $25 \mathrm{~km}$ due south (Zinsmeister and Paredes-Mejía, 1988). The late Paleocene paleogeographic picture is of a micrite-free, current-washed marine shelf separated from the mountains to the east at the same time areas to the north and south were still being inundated with coarse terrigenous sediments. Presumably, some local structural trough diverted the terrigenous sediments and allowed the carbonate sediments to accumulate.

\section{ACKNOWLEDGEMENTS}

We thank Jorge Ledesma-Vázquez and José Luis Fermán-Almada for first introducing us to the geology of Mesa de I a Sepultura. Our interpretations of the geologic history at Mesa de La Sepultura have been invaluably aided by micropaleontologic analyses graciously provided by Dick Boettcher and Mike Mickey who examined the foraminifera, Stanley A. Kling provided the coccolith and siliceous microfossil data and Hideyo Haga inspected pollen and spores, all of Micropaleo Consultants, Inc. of San Diego and Encinitas. Coccolith analyses were also generously done by Dave Bukry of the U.S. Geological Survey in Menlo Park. A key identification of Tumitella peninsularis in the lowermost Sepultura Formation was made by Lou Ella Saul of the Los Angeles County Museum. Thin sections were prepared for us in a timely fashion by Kevin Bryan. Field assistance was given by Aaron Yoshinobu and Mischelle Mische. The manuscript was improved by the reviews of Miguel TéllezDuarte and Jorge Ledesma-Vázquez. cerca de $400 \mathrm{~m}$ de cambio hacia menor profundidad, así que debe de haber habido regresion o levantamiento

La Formación Rosario superior estuvo expuesta a procesos subaéreos de formación de suelo. No se sabe hasta la fecha cuánto registro sedimentario se ha perdido por esta combinación de intemperismo sumado a falta de depósito o erosión. Sin embargo, es probable que muchos millones de años no estén representados por roca y no se haya conservado la frontera entre Cretácico y Terciario.

Cuando se preservó nuevamente la sedimentación, en la Formación Sepultura durante el Paleoceno, empezó como depósitos conglomeráticos muy enérgicos en aguas marinas someras. Las tasas de sedimentación fueron bajas, como sugieren la abundancia de glauconita, la presencia de superficies con corrosión y la importancia de los depósitos de tormenta. La sedimentación del Paleoceno registra una profundización del agua marina y progresiva separación del flujo de sedimento terrígeno de las arenas y gravas metamórficas plutónico volcánicas. El miembro inferior exhibe otros rasgos indicativos dc un medio marino somero como son perforaciones, abundantes fósiles marinos invertebrados, canales encajados rellenos de conglomerado, turritélidos orientados, abundante glauconita y algas rojas.

I.as algas rojas coralinas viven en medios de salinidad marina normal y, dado que utilizan luz solar, están restringidas a la zona fótica (Wray, 1977). I os cambios morfológicos notados en las àlgas rojas son resultado de turbulencia y energía del agua, según lo demostró Bosence (1991). La variedad rodolita es típica de condiciones de mayor energía mientras que las formas ramificadas se encuentran en aguas más tranquilas, muy probablemente más profundas. Bosence enumera también los alcances batimétricos, de 40 a $100 \mathrm{~m}$, de Lithothamnion y Archeolithothamniun. El incremento de algas rojas ramificadas y la disminución de rodolitos, en la parte de arriba, corresponde a un modelo de aguas que se hacen más profundaș. Los datos de micropaleontologia sobre los foraminíferos sugieren un ambiente de plataforma de media a exterior para el miembro calizo superior.

Adicionalmente, Adey y Macintyre (1973) listaron Archeolithothamnium como un género de aguas calientes y Lithothamnium. como uno de aguas frías. Ambos géneros se encuentran juntos en Mesa de la Sepultura, lo 


\section{REFERENCES}

Adey, W.H. and Macintyre, I.G. (1973). Crustose coralline algae: a re-evaluation in the geological sciences. Geological Society America Bulletin, 84: 883-904.

Beal, C. (1924). Informe sobre la exploración geológica de la Baja California, por la Marland Oil Company of México. Boletín del Petrólen, 17: $417-453$ y 18: 14-53.

Beal, C. (1948). Reconnaissance of the geology and oil possibilities of Baja California. Geological Society America Memoir 31, $138 \mathrm{pp}$.

Bosence, D.W.J. (1991). Coralline-Algae: mineralization, taxonomy, and palaeoecology. In: R. Riding (ed.), Calcareous Algae and Stromatolites. Springer-Verlag, New York, pp. 98-113.

Dickinson, W.R., Beard, L.S., Brakenridge, G.R., Erjavec, J.L., Ferguson, R.C., Inman, K.F., Knepp, R.A., Lindberg, F.A. and Ryberg, P.T. (1983). Provenance of North American Phanerozoic sandstones in relation to tectonic setting. Geological Society America Bulletin, 94: 222-235.

Gastil, R.G., Phillips, R.P. and Allison, E.C. (1975). Reconnaissance geology of the state of Baja California. Geological Society America Memoir 140, $170 \mathrm{pp}$.

Ginsburg, R., Rezak, R. and Wray, J. (1971). Geology of Calcareous Algae. Comparative Sediment. Lab., Univ. Miami, 64 $\mathrm{pp}$.

Goudkoff, P.P. (1945). Stratigraphic relations of Upper Cretaceous in Great Valley, California. American Assoc. Petroleum Geologists Bull., 29: 956-1007.

Kilmer, F.H. (1963). Cretaceous and Cenozoic stratigraphy and paleontology, El Rosario area, Baja California, Mexico. Ph.D. dissertation, Univ. California, Berkeley, $216 \mathrm{pp}$.

Ledesma-Vázquez, J. (1991). Upper Cretaceous-Paleocene storm deposits in Baja California, Mexico. M.S. thesis, San Diego State Univ., $81 \mathrm{pp}$.

Miller, V.V. and Abbott, P.L. (1988). Sedimentology of the Upper Paleocene/Lower Eocene Sepultura Formation near Colonet, Baja California. In: M.V. que indica que estas rocas se depositaron en alguna latitud media, donde las distribuciones geográficas de dichos géneros pudieron traslaparse.

Por el Paleoceno temprano tardío, sólo se acumulaban sedimentos de carbonato (junto con cantidades menores de filosilicatos), aun cuando se hayan depositado, al mismo tiempo aparentemente, arenas gruesas $y$ gravas terrígenas en San Telmo, $110 \mathrm{~km}$ al norte (Miller y Abbott, 1988) y en Mesa San Carlos, $25 \mathrm{~km}$ hacia el sur (Zinsmeister y Paredes-Mejía, 1988). La imagen paleográfica del Paleoceno tardío es la de una plataforma marina libre de micrita lavada por la corriente, separada de las montañas al este, mientras áreas del norte y sur seguian todavía inundadas con bastos sedimentos terrígenos. Probablemente, alguna depresión estructural desvió los sedimentos terrígenos y permitió que se acumularan los sedimentos de carbonato.

\section{AGRADECIMIENTOS}

Se agradece a Jorge Ledesma-Vázquezy José Luis Fermán-Almada la introducción al conocimiento de la geología de Mesa de la Sepultura. Las interpretaciones de la historia geológica de Mesa de la Sepultura fueron invaluablente apoyadas por análisis micropaleontológicos amablementeprovistos por Dick Boettcher y Mike Mickey, quienes examinaron los foraminíferos; Stanley A. Kling proporcionó los datos sobre cocolitos y microfósiles silíceos, y Hideyo Haga examinó polen y esporas; todos de Micropaleo Consultants, Inc. de San Diego y Encinitas. Los análisis de cocolitos fueron también generosamente realizados por Dave Bukry del U.S. Geological Sulvey en Parque Menlo. Una identificación clave de Tunitella peninsularis en la Formación Sepultura inferior fue realizada por Lou Ella Saul del Los Angeles County Museum. Kevin Bryan nos preparó secciones delgadas en forma oportuna. La asistència en el campo fue proporcionada por Aaron Yoshinobu y Mischelle Mische. El manuscrito fue mejorado con las revisiones de Miguel TéllezDuarte y Jorge Ledesma-Vázquez. Mora.

Traducido al español por Olivia Gómèz 
Filewicz and R.L. Squires (eds.), Paleogene Stratigraphy, West Coast of North America. Pacific Section, Soc. Econ. Paleontologists Mineralogists, 58: 23-34.

Patterson, D. (1978). The foraminiferal biostratigraphy and paleoecology of the type Rosario Formation, El Rosario, Baja California del Norte, Mexico. M.A. thesis, Univ. California, Santa Barbara, $150 \mathrm{pp}$.

Santillán, M. y Barrera, T. (1930). Las posibilidades petrolíferas en la costa occidental de la Baja California entre los paralelos $30^{\circ}$ y $32^{\circ}$ latitud norte. Anales del Instituto Geológico de México, 5: 1-37.

Van der Plas, L. and Tobi, A.C. (1965). A chart for judging the reliability of point counting results. American J. Science, 263: 87-90.
Van Houten, F.B. and Purucker, M.E. (1984). Glauconitic peloids and chamositic ooids - favorable factors, constraints, and problems. Earth-Science Reviews, 20: 211-243.

Wray, J. (1977). Calcareous Algae. Elsevier Scientific Pub., 185 pp.

Zinsmeister, W.J. and Paredes-Mejía, L.M. (1988). Paleocene biogeography of the west coast of North America: a look at the molluscan fauna from Sepultura Formation, Mesa San Carlos, Baja California Norte. In: M.V. Filewicz and R.L. Squires (eds.), Paleogene Stratigraphy, West Coast of North America. Pacific Section, Soc. Econ. Paleontologists Mineralogists, 58: 9-22. 